\title{
EDUCATIONAL ACTIVITY OF AGRITOURISM FARMS IN POLAND (ON EXAMPLES FROM THE POMERANIAN REGION)
}

\author{
Anna WIŚNIEWSKA \\ Pomeranian University in Slupsk, Institute of Social and Economic Geography and Tourism, \\ Partyzantów 27 , 76-200 Słupsk, Poland, e-mail: anna.wisniewska@apsl.edu.pl \\ Wioletta SZYMAŃSKA* \\ Pomeranian University in Słupsk, Institute of Social and Economic Geography and Tourism, \\ Partyzantów 27, 76-20o Słupsk, Poland, e-mail: wioletta.szymanska@apsl.edu.pl
}

Citation: Wiśniewska A. \& Szymańska W. (2020). EDUCATIONAL ACTIVITY OF AGRITOURISM FARMS IN POLAND (ON EXAMPLES FROM THE POMERANIAN REGION). GeoJournal of Tourism and Geosites, 28(1), 140-15o. https://doi.org/10.30892/gtg.28111-458

\begin{abstract}
The main aim of the article is to present the educational function of agritourism developing in a region of Poland which is unique in terms of its natural environment and cultural heritage. The educational function of agritourism is more and more often emphasized in scientific research. The best developed network of agritourism farms in Poland is in the Province of Pomerania with over 600 of them. Despite strong competition on the market, Pomeranian farmers have noticed opportunities for development of their farms through educational activities and the countryside has become a place of education in the scope of agriculture, folk culture and ecology. The research involved nearly $10 \%$ of active agritourism farms. The results of the surveys and direct questionnaire interviews confirmed great involvement of the agritourism farms in the development of various forms of education. The abundance and variety of those forms are present in the organization of educational activities, participation in farm work, getting familiar with the offer of folk artists, learning about regional and local culinary traditions as well as ecological education.
\end{abstract}

Key words: Poland, region, Pomerania, agritourism, agritourism farm, education, educational activity

\section{INTRODUCTION}

The term of agritourism refers to farm-based recreation in an area of rural character with accommodation and recreational facilities connected with an operating farm (of production), the surrounding nature and production and service facilities (Drzewiecki, 1995; Wiatrak, 1996; Majewski, 2000; Marks et al., 2006; Ożdziński, 2009; Petroman et al., 2016; Staciwa, 2018). It is based on the attractiveness of the natural environment and landscape and creates and protects the natural, agricultural

\footnotetext{
${ }^{*}$ Corresponding author
} 
and cultural heritage of rural areas (Polucha et al., 2003). In the light of the European Union strategy for multifunctional development of rural areas, it brings significant economic, social and educational effects (Petroman et al., 2016; Sikora, 2016).

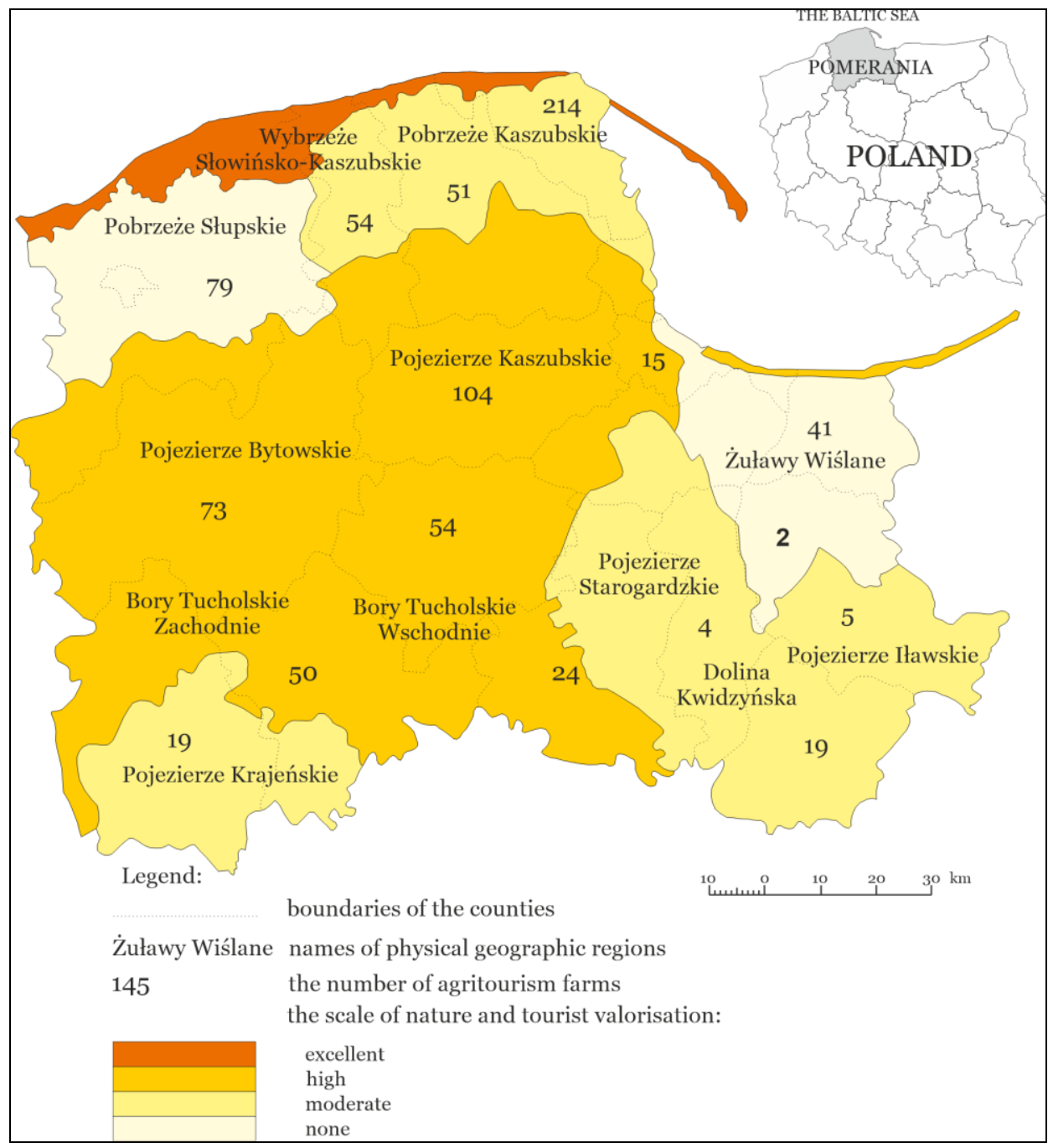

Figure 1. Nature and tourist valorisation of physical geographic regions in the Province of Pomerania (together with the number of agritourism farms in the counties) in 2011 (Source: based on Przewoźniak, 2002; Wiśniewska, 2017, p. 50)

A great deal of attention has been paid to agritourism in scientific research and in practical actions of decision-making bodies (local authorities, agritourism associations, agricultural advisory centres). That is mainly because agritourism is perceived as a multifunctional tool for the development of rural areas which provides additional jobs and income (Gralak \& Kacprzak, 2018). More and more often, a need to implement a new approach to the development of agritourism farms is emphasized as current strategies of accommodation providers seem to be ineffective and the competitiveness of agritourism offer basing on low prices is weak when compared to other forms of 
tourism (Balińska, 2017; Chiodo et al., 2019; Sidali at al., 2019). In recent years, special attention has been paid to the educational function of agritourism development.

Although the phenomenon is not well known yet, it is emphasised that agritourism has significant impact on expanding the knowledge about rural culture (Benea \& Petroman, 2006; Mot \& Petroman, 2014; Petroman et al., 2014). It also makes people aware of their local identity (Momir et al., 2014), facilitates the dissemination of information about the use of local natural resources and rural community heritage to create new products and art (Constantin, 2014; Herman et al., 2019; Gozner et al., 2017; Ilieş et al., 2016, 2017, 2018; Lincu et al., 2018). Moreover, it helps to shape the awareness of children and youth about educational opportunities in the spheres connected with rural areas (Holmes \& Tschanz, 2004; Petroman et al., 2015).

The main aim of the study is to present the educational function of agritourism farms in the Province of Pomerania in Poland where agritourism is developing rapidly due to the unique natural environment, coastal location as well as unique cultural heritage of ethnographic regions such as Kashubia, Kociewie, Krajny and the Tuchola Forest. In terms of agritourism development, the Province of Pomerania is in the Poland's forefront. According to the estimates of the Ministry of Agriculture and Rural Development, there were 672 agritourism farms with 7595 beds in Pomerania in 2014.

Since the beginning of the 1990s, a dynamic development of agritourism has taken place mainly in the areas with valuable nature, which are exceptionally attractive or very attractive in terms of nature and tourism, namely on the Słowiński and Kashubian Coast, the Bytowski and Kashubian Lake Districts and the Tuchola Forest (Figure 1). Despite strong competition on the market, Pomeranian farmers have noticed opportunities for development of their farms through educational activities and the countryside has become a place for education in the scope of agriculture, folk culture and ecology.

\section{MATERIALS AND METHODS}

The analysis of agritourism farms educational offer was based on one of survey methods, i.e. direct questionnaire interview. Interviews involved a group of 55 agritourism farms associated in the Gdańsk Agritourism Association (25) and agritourism associations called Sworacy (11) and Agro-Kaszuby (19). The address database and initial information about the farms were accessed from the official websites of the agritourism associations (http://www.kaszuby.agrowakacje.pl and http://www.infoturystyka.pl). This group included 3 ecological farms and 3 farms associated in the National Educational Farming Network. Primary research was carried out from March to November 2017. The detailed offer of individual agritourism farms as well as the information contained on the home pages of these entities were used in the analysis. While completing the assumed goals, other research methods were also applied, i.e. (open) observation, and analyses of subject literature, statistical data, photographic and cartographic documentation.

\section{RESULTS}

\section{Educational values of agritourism farms}

Agritourism activity run on farms has a wide educational impact as it satisfies diverse cognitive needs of tourists, especially children and adolescents.

Education is accomplished through action, gaining experience, being, working and experiencing emotions in a group, playing, learning and discovering as well as developing senses and expressive skills (Chojnacka-Ożga et al., 2007) and proves detailed educational values of an agritourism farm (Table 1). In the case of children and youth, the best way to teach is through play which allows to draw the students' attention away from the educational process. Thus, they learn somehow unwittingly in the process and those involved in the play decide themselves how much they learn. 
Educational Activity of Agritourism Farms in Poland (On Examples From the Pomeranian Region)

Table 1. Educational values of an agritourism farm

(Data source: based on Chojnacka-Ożga et al., 2007, p. 190)

\begin{tabular}{|l|l|}
\hline \multicolumn{1}{|c|}{ Educational values } & \multicolumn{1}{c|}{ Comments } \\
\hline Learning by acting & $\begin{array}{l}\text { Direct experience through action: observation, touch, testing, self- } \\
\text { discovery of nature, agricultural products and farmer's work. }\end{array}$ \\
\hline Learning methods & $\begin{array}{l}\text { Acquiring skills that improve the overall efficiency of learning processes } \\
\text { (ability to observe, analyze, compare, communicate) }\end{array}$ \\
\hline $\begin{array}{l}\text { Experiencing } \\
\text { emotions }\end{array}$ & $\begin{array}{l}\text { Situations accompanied by emotions (close contact with animals, } \\
\text { activities in the environment of nature) are remembered better and } \\
\text { shape the personality of man. }\end{array}$ \\
\hline $\begin{array}{l}\text { Learning } \\
\text { to stay and work } \\
\text { in a team }\end{array}$ & $\begin{array}{l}\text { Development of psycho-social skills and socialization: teaching children } \\
\text { to stay and work in a team - joint decision making, mutual cooperation, } \\
\text { coordination of activities. }\end{array}$ \\
\hline Playing & $\begin{array}{l}\text { Didactic animation is based on play, which stimulates the motivation to } \\
\text { learn and is an effective way to shape children's love of the countryside. }\end{array}$ \\
\hline $\begin{array}{l}\text { Studying and } \\
\text { discovering }\end{array}$ & $\begin{array}{l}\text { Independent search for answers to various questions (joy when you } \\
\text { manage to find them); careful observation, asking questions, comparing } \\
\text { hypotheses and explanations about the life of plants and animals with } \\
\text { what you can see in the countryside. }\end{array}$ \\
\hline Developing senses & $\begin{array}{l}\text { Influence of sounds, smells and flavours on children's senses, developing } \\
\text { the ability to perceive signals from the environment and the ability to } \\
\text { recognize food products. }\end{array}$ \\
\hline $\begin{array}{l}\text { Developing the } \\
\text { ability of expression }\end{array}$ & $\begin{array}{l}\text { Freedom of activity favours the expression of personality, development of } \\
\text { creativity and expression primarily thanks to manual work. }\end{array}$ \\
\hline $\begin{array}{l}\text { Getting to know } \\
\text { rural culture }\end{array}$ & $\begin{array}{l}\text { Getting to know the life and work of past generations in the countryside, } \\
\text { rural traditions and customs, proverbs taking their origin in the wisdom } \\
\text { of the residents. }\end{array}$ \\
\hline Gaining experience & $\begin{array}{l}\text { Acquiring knowledge through experience in an environment other than } \\
\text { the classroom. }\end{array}$ \\
\hline
\end{tabular}

Pomeranian agritourism farms promote the above values which can be exemplified by the implemented projects i.e. the farmer's eye (an educational visit in the countryside), village toys (hay and straw matting workshops), rural Olympics and manual workshops (come and paint my world or cross-country paperchase). The above values are fully applied in the green school types of projects. In the nineties, it became popular to receive school trips, during which children and youth were educated in the field of ecology, a produce path of life from the field to the table or cultural wealth of given regions. Currently, the offer for green schools is being expanded and modified.

Although the educational offer of farms is aimed primarily at children and adolescents, it does not exclude the participation of other types of tourists. Due to the wide range of such activities, they can be targeted at people of various education, age, needs, interests and socio-economic status. Apparently, older people studying at the universities of the third-age (from Gdynia, Gdańsk, Sopot and Słupsk) have become a significant group of recipients of educational services on the surveyed farms recently.

\section{Educational activities carried out on Pomeranian agritourism farms}

Educational activity carried out on Pomeranian agritourism farms takes place in many spheres and is related to the following areas: farmer's life and work, the process of food production and acquisition, preparation of regional dishes, cultural heritage of the Polish countryside and shaping the right attitudes towards nature and landscape protection (Figure 2). Basic educational activity of agritourism farms involves showing life in the countryside and getting to know the farmer's work. $67 \%$ of the farms under study declared the opportunities of observing production processes and field work. The remaining farms did not conduct this type of activity - they were 
mostly farms located in the coastal area and supporting themselves mainly from income from tourism. On $80 \%$ of the farms, other farm work could be observed such as taking care of rabbits, birds, horses, goats or domestic animals. Specifically geared educational activities in this area were offered by $18 \%$ of the surveyed farms. The initiatives showing life in the countryside included classes called $A$ farmer's day - the secrets of everyday farm activities and Farmer's life or Countryside is fun.

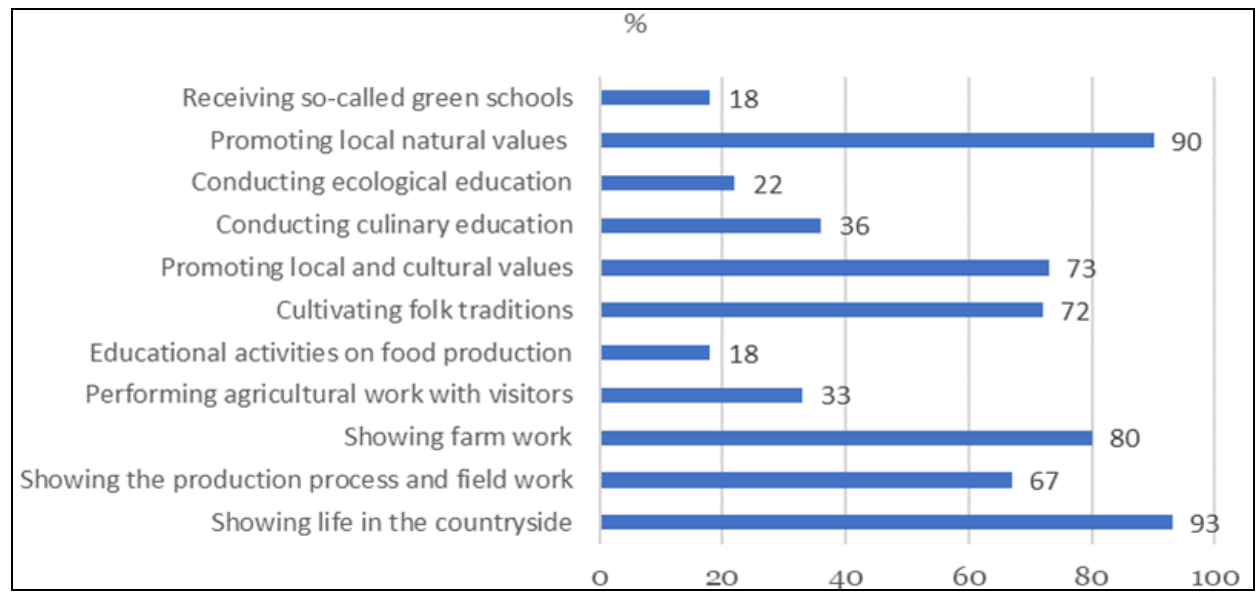

Figure 2. Educational activities carried out on Pomeranian farms in Poland in 2017

Amateurs of farm-based recreation - users of agritourism services - expand their knowledge and skills during their stay on the farm by being able to actively participate in the process of food production and acquisition. According to the surveyed hosts, through help and direct participation in the production activity, the tourists get to know the part of the farm that has a useful function including fruit orchards, vegetable gardens, apiaries or herb gardens, as well as cowsheds and farms. $33 \%$ of the farms offered the opportunities of active participation in the production processes and field work together with the hosts. The offer mainly included picking fruit, milking cows and goats and feeding animals (Figure 3). For reasons of safety of the guests, the hosts reluctantly allowed for active participation in field work.

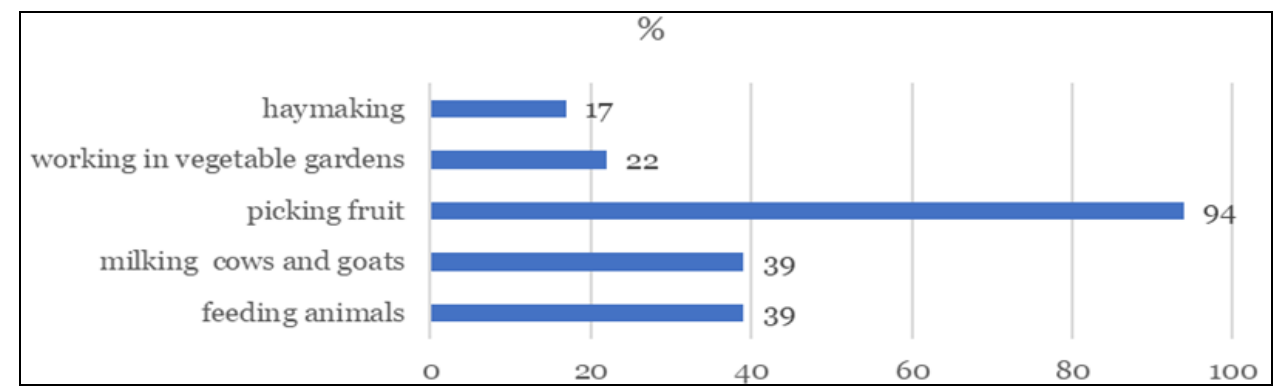

Figure 3. The possibility of active participation in production processes

and field work on agritourism farms in the Province of Pomerania in Poland in 2017

Contact with breeding animals on the farm is a great tourist attraction as well as a form of education. Interested tourists can see how much work is needed in order to acquire various food products of animal origin (Marks et al., 2007). Examples of 
educational activities showing the process of food production and acquisition in the researched farms include lessons about milk, lessons about cereals, horse breeding and use, dairy farming and milking, from grain to bread shows, lavender stories, talks on why we breed animals, why we grow plants, the world of horses, the world of the mother hen, the world of bunnies, the role of bees in nature, the life of ostriches, the world of wool and sheep, crops and wild plants, herbs in nature. $18 \%$ of the farms included the above presented educational activities in their offers. Another area of education is to familiarize tourists with the cultural heritage of the Pomeranian villages. Visitors learn about the local customs, rituals and folk traditions. Culture means the whole of material and non-material creations of human activity, values and methods of conduct, recognized, objectified and adopted in a given community, transferred to other communities and next generations (Szczepański, 1970). Agritourism is a medium of knowledge for tourists whereas for a village and an agritourism farm, it is a method for saving cultural heritage from oblivion (Firlik, 2007). It creates a possibility of comparing the proper culture in the place of residence of tourists with rural culture. On the one hand, it shows the diversity of these cultures. On the other hand, it teaches tolerance and creates the basis for dialogue between them (Sikorska-Wolak, 2007; Sadowski \& Wojcieszak, 2019).

The results of field observations allow to state that there has been a return to old rituals, customs and preservation of traditions in the rural area of the Province of Pomerania. Folklore activities of folk bands, regional cuisine and folk crafts are cultivated as well. The Kashubian and Kociewie patterns are the most vital on the farms under study. Since May 2005, the Kashubian language has been the second official language in 10 communes of the Province of Pomerania (along with dialects: Kociewie, Krajna, Tuchola and new mixed dialects). A part of the village residents aware of the natural and cultural values of the region use these resources in their development plans (Czapliński \& Szymańska, 2013). The aesthetics of the countryside is significantly improving thanks to Pomeranian Rural Renewal Programmme, Beautiful Countryside competition or the Checkered Land project (Wiśniewska, 2017). Dissemination of knowledge about local traditions was included in the offer of over $70 \%$ of the surveyed farms (Figure 4).

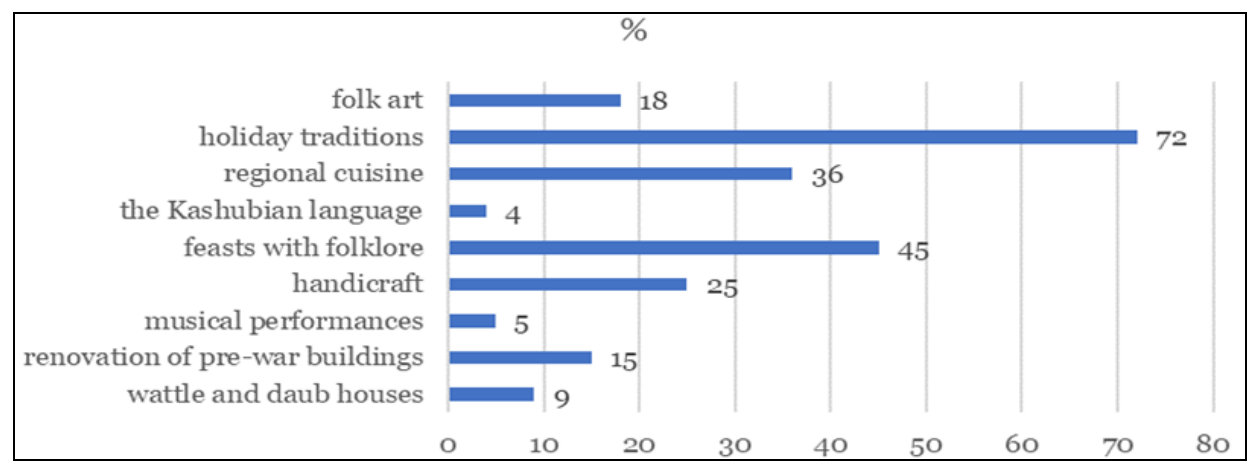

Figure 4. Cultivated local customs and folk traditions on Pomeranian agritourism farms in the Province of Pomerania in Poland in 2017

On Pomeranian agritourism farms tourists can learn to create cut-outs and weave, embroidery, pottery, wickerwork, jewellery production, sculpture. They can also learn to paint, sing and dance. Starting up folk bands is popular as well. Agritourism providers can see a growing demand for so-called folk culture as more and more customers are interested in folk products and they take advantage of it to develop their own businesses. Regional products are becoming trendy again as well. After the crisis of 
1990-1992, a slight improvement took place in 1994 (Wierzchowska, 2005), and since then this trend has become more and more popular largely thanks to foreign tourists and art collectors. Currently, almost all guests are interested in folk culture.

The surveyed hosts in Pomerania proudly displayed renovated huts, farmsteads, fences, houses, gates, barns, granaries, roadside shrines or fishing houses. In the coastal area, distinctive cultural elements in the studied farms were: preserved wattle and daub buildings and cultivating the Slovincian tradition. Some of the hosts made guests familiar with specific seaside songs and legends, for example about ghostly fishing boats, monstrous fish and fire people. Nearly $25 \%$ of farms in this region offered regional cuisine based on marine fish and poultry (goose meat).

On numerous farms of the Bytowski and Kashubian Lake Districts, many Kashubian traditions are cultivated including embroidery, pottery and ceramics (with specific colours and floral motifs). Some of the hosts and household members are able to communicate in the still used Kashubian language (4\%). The hosts also emphasized the participation of their family members in numerous folklore groups and folk bands. Some of them used the so-called Kashubian notes. Tourists on agritourism farms in these regions could get acquainted with Kashubian music including the Kashubian anthem. The Kashubian cuisine was served in nearly a quarter of the farms in the Bytów region and about 70\% of the farms in the Kościerzyna region provided food. Most often the offers of the researched farms included such delicacies of the Kashubian cuisine such as: slédze z pulkami (salted herrings with potatoes), szmurowanô wotowina (stewed beef with dried mushrooms) and miodny $i$ kwasny bonk (sweet and sour bean soup).

The Kashubian and Borowiacki traditions are cultivated on the farms of the Tuchola Forest region due to its great ethnic diversity. The hosts have renovated and maintained the specific architecture including: wooden cottages, farms with a well in the middle, rail fences and fences made with interlacing poles, outbuildings and granaries.

Folk traditions are also reflected in music, ceramics and sculpture. Nearly one third of the farms offering board serve traditional cuisine (e.g. dukacz, otherwise known as mashed potatoes with milk, bacon and onion, soups: carrot soup, eel broth, mushroom soup and czernina (soup made of duck's blood). All aspects of culinary culture deserve particular attention when it comes to the rural tourism market, including traditional raw materials and food products, eating habits, methods of preparing food, and the process of consumption itself. Visible interest in the culinary heritage of rural areas is an opportunity for the development of local entrepreneurship and the preservation of folk culture related directly or indirectly to food (Orłowski \& Woźniczko, 2015).

Culinary education is also conducted on Pomeranian agritourism farms. The agritourism providers offered various educational activities that were directed to tourists of all age groups, and their main goal was to acquire or develop practical skills related to learning about regional cuisine. In addition to offering their own culinary products, it was possible to participate in their preparation and production together with the hostess. Tourists had an opportunity (within the specifics of the offered culinary products) to participate in the entire production cycle from the stage of harvesting agricultural products to the final product on the plate (Dorocki \& Struś, 2015). The hosts serving regional cuisine encouraged guests to learn about local culinary traditions. Research shows that tourists appreciate educational values that are associated with participation in kitchen work, learning how to prepare regional dishes and drinks, and acquiring skills related to traditional food processing (Marks et al., 2007). Among the culinary educational activities distinguished by Orłowski (2008), the offers of $36 \%$ of the surveyed agritourism farms in Pomerania included:

- traditional bread baking, 
- baking cakes and cookies - for holidays or rituals,

- making and forming butter,

- manufacture of pressed cottage cheese,

- meat preservation - drying, salting, smoking,

- meat processing - production of sausages, brawn, black sausage, jellies, cold meats,

- smoking and processing of freshwater and marine fish,

- fruit and vegetable processing, i.e. pickling cabbage, pickling cucumbers, drying fruit, making juices, preserves, marmalades, jams and powidta (a type of jam made from plums),

- drying herbs and mushrooms,

- traditional picking and spinning of honey in an apiary located in a fruit orchard or garden,

- preparing non-alcoholic beverages from forest and garden fruits - various types of low-alcohol beverages made from beetroot or bread, birch, maple, mint or elderberry flowers drinks as well as home brew and acorn coffee,

- preparing alcoholic beverages - fruit and herbal tinctures, meads, light and dark beers,

- preparing regional dishes.

Some of the farms (27\%) offered regional dishes produced with the use of traditional equipment, such as: coal stoves, pots, pans, pokers, wooden shovels, churns, barrels, moulds, cheese presses, shredders, stoneware pots and copper cauldrons. On $45 \%$ of the farms, socalled culinary feasts were offered - tasting regional dishes and traditional food products prepared according to recipes passed from generation to generation. The offers of most farms under study included Kashubian feasts (with singing, dancing, boar, piglet or ram). Nearly $9 \%$ of the farms organized culinary demonstrations combined with cooking classes for various age groups of tourists interested in learning about the rural culinary heritage.

The educational function of agritourism is also fostered by i.a. creating conditions for learning about the local cultural heritage and organizing educational routes based on cultural values. $73 \%$ of the surveyed farms included information about cultural facilities and local events in their offers. In the coastal area, the most frequently visited museums were: the Museum of Pomeranian Dukes, the Museum of the Puck Land, the Museum of the Slovincian Village and various events such as traditional peat extraction called the Black Wedding or the sale of local products at the Dominican Fair. Rzucewo was also promoted as a former settlement of seal hunters from the Stone Age as well as Swołowo, so called Chequered Land. In the Kashubian and the Tuchola Forest regions, apart from the Kashubian Museum, T. and I. Gulgowscy Kashubian Ethnographic Park Museum, the Tuchola Forest Museum, the National Anthem Museum and the Kashubian Ceramics Museum, tourists were encouraged to visit the Wdzydze Fair, the Kościerzyna Fair of Kashubian and Pomeranian Books, Tczew Land Days "Heritage for the Contemporary" or "Days of Żuławy" in Nowy Dwór Gdański and the annual Kashubian reunions.

Another very important educational aspect of agritourism farms is the opportunity to shape appropriate attitudes towards nature and landscape protection.

Nearly 90\% of the surveyed farms promoted local natural and landscape values in their offers, the protected areas in the first place. Ecological education is conducted on some Pomeranian farms (22\%), mostly on the farms located in the protected areas or in their vicinity. Nearly $90 \%$ of the households located near Słowiński National Park and $84 \%$ of the Tuchola Forest National Park emphasize the possibility of using the resources of these entities. At the same time, the centres of ecological education located in the parks or designated didactic paths were indicated as perfect places to visit by tourists staying in the countryside. The offers of $18 \%$ of the surveyed entities included natural and ecological workshops addressed to children and young people staying on the farms under the so-called green school project. During the classes, participants followed didactic paths on the farm or in its surroundings (with stops in the garden, in the field, in the meadow, in the forest). They also took care of the farm animals or 
worked in the garden (garden cultivation using ecological methods). Activities on the subject of preserving the culinary heritage were also offered. The aim of education in green schools was to shape ecological awareness, show life in accordance with the laws of nature and prevent the consequences of over-exploitation of natural resources.

However, it should be emphasised that educational activities undertaken on farms should contribute to the dissemination and deepening of knowledge about nature as well as shape the tourist's sensitivity (Kurczewski, 2007). Unfortunately, in the Pomeranian villages, attitudes that contradict this idea are not uncommon, e.g. improper care of animals (keeping dogs on chains, lack of veterinary care for cats) or other behaviours, such as burning garbage, leaves or stubble fields. Some of the farmers are characterized by little knowledge of the issues of broadly understood environmental protection despite considerable efforts of Agricultural Advisory Centres.

It is worth emphasizing that the educational activity of Pomeranian agritourism farms can be conducted in an organized and formalized form. In 2011, a project of the National Educational Farming Network was implemented (Poland ... 2013) at the initiative of the Agricultural Advisory Centre in Brwinów (Cracow Branch) and with the financial support of the Ministry of Agriculture and Rural Development.

This network aims at disseminating the idea of education on farms and promotes the activities of educational farms. The educational offer includes demonstrations and workshops actively engaging children, youth, families with children and adults. The purpose of the network of educational farms located in rural areas is to raise the prestige of the farmer's job and disseminate knowledge about the origin of food, a diversity of non-agricultural activities and preservation of the cultural heritage of the countryside. Visitors learn about life in the countryside and can acquire knowledge and education in the scope of: agricultural and animal production, crops processing, ecological and consumer awareness, material culture heritage of the country, traditional jobs and trades, handicrafts and folk art. In 2018, 21 entities were associated in the National Network of Educational Farms in Pomerania in Poland.

\section{CONCLUSION}

Since the beginning of the nineties, Pomeranian agritourism farms and the rural environment have become a place of education in the field of agriculture, folk culture and ecology. The educational offer includes shows, games, contests, workshops, outdoor activities which actively engage children, youth, families with children and adults. Visitors learn about life in the countryside and acquire knowledge about agricultural production, breeding animals or processing crops. One third of the farms offer active participation in those processes. The material and non-material culture of the Pomeranian villages is a very important element of the educational offer of the farms. The Kashubian and Kociewie patterns are the most outstanding among the entities under study. Handicraft and folk products offered by the farms are generating more and more interest.

Tourists can learn to make cut-outs, paint, sing and dance as well as embroidery, weaving, pottery, wickerwork, jewellery production and sculpture. A demand for folklore activity of folk bands is evident. It is also becoming popular to cultivate regional culinary traditions (especially in the Kashubian region). Culinary education is carried out on some of the farms in the form of workshops, demonstrations and culinary feasts with local folklore. Local natural and cultural values are eagerly promoted in the offers of agritourism farms. On the other hand, conducting ecological education is most often declared by owners who operate in the protected areas or in their neighbourhood. The farms located in the vicinity of Słowiński National Parks and the Tuchola Forest offer natural and ecological workshops addressed to children and young people (as part of the green school project). In 2018, 21 farms joined the National Network of Educational Farms. Summing up, it can be stated that all educational activities carried out on the 
agritourism farms under study contribute to the dissemination and broadening of knowledge about the farmer's life and the natural and cultural environment of the Pomeranian villages. They shape the sensitivity of tourists and lead to raising ecological awareness. It is of vital importance to develop and promote a wider educational offer.

\section{REFERENCES}

Balińska A. (2017). Konkurencyjność agroturystyki jako formy spędzania czasu wolnego (Competitiveness of agritourism as a form of spending leisure time), Prace Naukowe Uniwersytetu Ekonomicznego we Wrocławiu, 473, p. 37. (in polish).

Benea M.,\& Petroman I. (2006). Bazele turismului, Editura Eurostampa, Timisoara.

Chiodo, E., Fantini, A., Dickes, L., Arogundade, T., Larnie, R.D., Assing, L., Stewart, C., \& Salvatore, R. (2019). Agritourism in Mountainous Regions - Insights from an International Perspective, Sustainability, 11, 3715, doi:10339o/su11133715, accessed 10.09.2019.

Chojnacka-Ożga, L., Ożga, W. \& Kobiałka, W. (2007). Gospodarstwa dydaktyczne jako jedna z form działalności agroturystycznej na przykładzie włoskiej Prowincji Mantui (Didactic farms as a form of agritourism activity on the example of the Italian Province of Mantua), in: Sikorska-Wolak, I., (ed.) Turystyka w rozwoju obszarów wiejskich (Tourism in the development of rural areas), Wyd. SGGW, Warszawa, s. 190. (in polish).

Constantin, E. C. (2014). The Need for effective communication. Elsevier, Procedia - Social and Behavioral Sciences, Volume 116, 21, p. 2010-2014.

Czapliński, P. \& Szymańska, W. (2013. The features of economic behavior of the Urban population in the ethnic the region of Kashubia (Kashuby/Cassubia), Miscellanea Geographica - Regional Studies on Development, Vol 17, no 2, pp. 30-37.

Dorocki, S. \& Struś, P. (2015). Regionalne zróżnicowanie turystyki kulinarnej na terenach wiejskich Francji (Regional differences in culinary tourism in the rural areas of France). Turystyka Kulturowa, 7, p. 6-17. (in polish).

Drzewiecki, M. (1995). Agroturystyka. Założenia - uwarunkowania - działania (Agritourism - Assumptions conditions - activities), Instytut Wydawniczy „Świadectwo”, Bydgoszcz , p. 27. (in polish).

Filrlik, I. (2007). Kultura bogactwem turystyki wiejskiej, czyli o skarbach ukrytych w puszczy (Culture - the wealth of rural tourism - on treasures hidden in the wilderness), in: Sikora, J., (ed.), Turystyka wiejska a edukacja. Różne poziomy, różne wymiary (Rural tourism and education. Different levels, different dimensions), Wyd. Akademii Rolniczej w Poznaniu, Poznań, p. 203-208. (in polish).

Gozner, M., Tătar, C.F., Stupariu, M. \& Măduta, F.M. (2017). Nature, Photography and Tourism in Bihor Vlădeasa Mountains (Romania). GeoJournal of Tourism and Geosites, Year X, Volume 20, Oradea Gdansk, Romania-Poland, Editura Universităţii din Oradea

Gralak K., Kacprzak M. (2018). Agroturystyka w rozwoju obszarów wiejskich w Polsce - stan, problemy i perspektywy (Agritourism in the development of rural areas in Poland - its state, problems and prospects), Zeszyty Naukowe. Turystyka i Rekreacja, 2(22), pp.187-195. (in polish)

Herman, G.V., Wendt, J. A., Dumbravă, R., Gozner, M. (2019). The role and importance of promotion centers increating the image of tourist destination: Romania. Geographia Polonica, 92(4), 443-454.

Holmes K., Tschanz, Y. (2004). Promoting Skills Development. U.N.E.S.C.O. International Institute for Educational Planning.

Ilies, D.C., Buhas, R., Ilies, M., Ilies, A., Gaceu, O., Pop, A.C., Marcu, F., Buhas, S.D., Gozner, M., \& Baias, S. (2018). Sport Activities and Leisure in Nature 2000 Protected Area - Red Valley, Romania. Journal of Environmental Protection and Ecology, 19, No 1, 367-372.

Ilies, A., Hurley, P., Ilies, D.C. \& Baias S. (2017). Tourist animation -a chance adding value to traditional heritage: casestudys in the Land of Maramures (Romania). Revista De Etnografie Si Folclor, New Series 1-2.

Ilieș, A., Wendt, J.A., Ilieș, D.C., Herman, G.V., Ilieș, M. \& Deac, A.L. (2016). The patrimony of wooden churches, built between 1531 and 2015, in the Land of Maramuress, Romania. Journal of Maps, Volume 12, 2016, pp 597-602 - Issue sup1 (http://dx.doi.org/10.1080/17445647.2016.1243075).

Kurczewski, R. (2007). Edukacja ekologiczna w agroturystyce (Environmental education in agritourism), in: Sikora, J., (ed.), Turystyka wiejska a edukacja. Różne poziomy, różne wymiary (Rural tourism and education. Different levels, different dimensions), Wyd. Akademii Rolniczej w Poznaniu, Poznań, p. 252-259. (in polish)

Lincu, A., Ilieș, M., Ilieș, D.C., Herman, G.V., Baias, S., Gozner, M., Costea, M., \& Mihincău, D. (2018). Conservating the traditional cellars of Salacea, Bihor County, Romania. GeoJournal of Tourism and Geosites, 23(3), 748-758, https://doi.org/10.30892/gtg.23311-325.

Maddala, G., S. (2006). Ekonometria (Econometrics), Wyd. Naukowe PWN, Warszawa. (in polish).

Majewski, M. (2000). Agroturystyka to też biznes (Agritourism is also business), Fundacja Wspomagania Wsi, Warszawa, p. 8. (in polish).

Marks, M., Jaszczak, A. \& Marks, E. (2007). Relacje między agroturystyką a edukacją środowiskową (Relations between agritourism and environmental education), in: Sikora, J., (ed.), Turystyka wiejska a edukacja różne poziomy, różne wymiary (Rural tourism and education. Different levels, different dimensions), Wyd. Akademii Rolniczej w Poznaniu, Poznań, p. 39-49. (in polish). 
Marks, M., Marks, E. \& Jaszczak, A. (2006). Działalność agroturystyczna i jej wpływ na zachowanie dziedzictwa kulturowego polskiej wsi (Agritourism activity and its influence on the preservation of cultural heritage of the Polish rural areas), in: Plichta, M., Sosnowski, J., (eds.), Marketing w agroturystyce (Marketing in agritourism), Wyd. Akademii Podlaskiej, Siedlce, s. 13-19. (in polish).

Momir B., Petroman I., \& Merghes P.E. (2014). Ecotourism- a major factor in the preservation of flora and fauna biodiversity in Banat, Facultatea de Management Agricol, Timisoara, seria I, vol XVI (4), p. 98-103.

Mot T. \& Petroman I. (2014). Rural and historic tourism potential of Seceani from the Timis county, Banat region, Scientific Papers Animal Science and Biotechnologies, Timisoara, vol.47. p. 334 -337.

Orłowski, D. (2008). Pożywienie ludowe jako znacząca atrakcja turystyki etnograficznej (Traditional food as an important attraction of etnographic tourism), in: Jalinik, M., (ed.), Innowacje w rozwoju turystyki (Innovations in tourism development). Wyd. Politechnika Białostocka, Białystok, s. 181-191. (in polish).

Orłowski, D. \& Woźniczko, M. (2015), Turystyka kulinarna na wiejskim rynku turystycznym turystycznym (Culinary tourism on the rural tourism market), in: Kamińska, W., (ed.), Innowacyjność w turystyce wiejskiej a nowe możliwości zatrudnienia na obszarach wiejskich (Innovation in rural tourism and new employment opportunities in rural areas), Studia KPZK PAN, t. CLXIII, Warszawa, s. 121-142. (in polish).

Ożdziński, J. (2009). The chances and threats of the development of rural tourism and recreation in Poland, GeoJournal of Tourism and Geosites, 2 (4), p. 174-178.

Petroman I., Marin Diana \& Petroman, C., (2015). Bazele Turismului, Editura Eurostampa, Timisoara.

Petroman, I., Csosz I.,Petroman I., Marin, D., Momir B. \& Bejan, C. (2014). Rural tourism products from the Banat area demanded by the European tourist, Scientific Papers Animal Science and Biotechnologies, Timisoara, vol.47 (1), p. 338-342.

Petroman, I., Varga, M., Constantin, E., C., Petroman, C., Momir, B., Turc, B. \& Merce, I. (2016). Agrotourism: An Educational Tool for the Students with Agro-Food Profile, Procedia Economics and Finanse, 39 (2016), p. 83-97.

Połucha, I., Młynarczyk, K., Marks, E., Marks, M. \& Jaszczak, A. (2003). Rural tourism in sustainable development of areas with unique environmental values, in: Globalization and integration challenges to the rural areas of East and Central Europe. Mat. Konf. Nauk., Lithuanian University of Agriculture and Lithuanian Institute of Agrarian Economics, Kowno, p. 146-148.

Przewoźniak, M. (2002), Waloryzacja przyrodniczo-turystyczna rejonów fizycznogeograficznych w województwie pomorskim (Nature and tourist valorisation of physical and geographical regions in Pomeranian Province), in: Pankau, F., (ed.), Raport o stanie zagospodarowania przestrzennego województwa pomorskiego (Report on the state of spatial development in the Pomeranian Voivodeship), Pomorskie Studia Regionalne, Urząd Marszałkowski w Gdańsku, Gdańsk. (in polish).

Sadowski, A. \& Wojcieszak, M.M. (2019), Geographic differentiation of agritourism activities in Poland vs. cultural and natural attractiveness of destinations at district level. PLoS ONE 14(9): e0222576. https://doi.org/10.1371/journal.phone.0222576, accessed 15.11.2019.

Sidali, K.L., Spitaler, A. \& Schamel, G. (2019), Agritourism: A Hedonic Approach of Quality Tourism Indicators in South Tyrol. Sustainability, 11, 3747, doi:103390/su11133747, accessed 10.09.2019.

Sikora, J. (2012). Agroturystyka. Przedsiębiorczość na obszarach wiejskich (Agritourism. Entrepreneurship in rural areas), Wyd. C.H. Beck, Warszawa. (in polish).

Sikora, J. (2016). Edukacja w agroturystyce (Education in agritourism), in: Jęczmyk, A., Uglis, J., Maćkowiak, M,. (eds.), Turystyka wiejska zagadnienia ekonomiczne i marketingowe (Rural tourism, economic and marketing issues), Tom I, Poznań, p. 9. (in polish).

Sikorska-Wolak, I. (2007). Turystyka jako system dydaktyczno-wychowawczy (Tourism as a didactic and educational system), in: Sikora, J., (ed.), Turystyka wiejska, a edukacja. Różne poziomy, różne wymiary (Rural tourism and education. Different levels, different dimensions), Wyd. Akademii Rolniczej w Poznaniu, Poznań, p. 12-21. (in polish).

Staciwa, A. (2018). Agroturystyka a turystyka wiejska (Agritourism versus rural tourism). Pomorski Ośrodek Doradztwa Rolniczego w Lubaniu, Słupsk, p. 2. (in polish).

Szczepański, J. (1970). Elementarne pojęcia socjologii (Basic notions in sociology), PWN, Warszawa. (in polish)

Wiatrak, A. (1996). Wpływ agroturystyki na zagospodarowanie obszarów wiejskich (Influence of agritourism on the development of rural areas), Zagadnienia Ekonomiki Rolnictwa, 1, p. 34-46. (in polish).

Wierzchowska, M. (2005). Własnymi rękami (With your own hands), Rzeczpospolita, 04.03.2005. (in polish)

Wiśniewska, A. (2017). Praca i dochody w pomorskich gospodarstwach agroturystycznych w latach 1999-2010 (Work and income in Pomeranian agritourism farms), Wyd. Akademii Pomorskiej w Słupsku, Słupsk, s. 54. (in polish).

*** (2013). Polska wieś i rolnictwo, Prezentacja wyników badania 2013, Ministerstwo Rolnictwa i Rozwoju Wsi (Polish countryside and agriculture, Presentation of research results 2013), Warszawa. (in polish)

http://www.zagroda-edukacyjna.pl/, accessed 15.10.2018.

http://www.infoturystyka.pl/, accessed 20.03.2017.

http://www.kaszuby.agrowakacje.pl/, accessed 20.03.2017.

Submitted:

18.10.2019
Revised:

10.02.2020
Accepted and published online 14.02.2020 